\title{
Fischer-Tropsch synthesis over Pd promoted cobalt based mesoporous supported catalyst
}

\author{
Pavan Kumar Gupta ${ }^{1}$, Abhishek Mahato ${ }^{1}$, Goutam Kishore Gupta ${ }^{2}$, Gajanan Sahu ${ }^{1}$, and Sudip Maity ${ }^{1, *}$ \\ ${ }^{1}$ Gasification, catalysis and CTL Research Group, CSIR - Central Institute of Mining and Fuel Research (Digwadih), \\ PO: FRI, Dhanbad, 828108 Jharkhand, India \\ ${ }^{2}$ Department of Chemical Engineering and Technology, Indian Institute of Technology (BHU), Varanasi 221005, India
}

Received: 1 May 2020 / Accepted: 19 January 2021

\begin{abstract}
The present study focuses on the catalytic conversion of syngas $\left(\mathrm{CO}+\mathrm{H}_{2}\right)$ through FischerTropsch (FT) route using two identically prepared 0.1 wt.\% palladium promoted Mesoporous Alumina (MA) and SBA-15 supported Co (15 wt.\%) catalysts. The Fischer-Tropsch activity is performed in a fixed bed tubular reactor at temperature $220^{\circ} \mathrm{C}$ and pressure 30 bar with $\mathrm{H}_{2} / \mathrm{CO}$ ratio $\sim 2$ having Gas Hourly Space Velocity (GHSV) of $500 \mathrm{~h}^{-1}$. Detail characterizations of the catalysts are carried out using different analytical techniques like $\mathrm{N}_{2}$ adsorption-desorption, Temperature-programmed reduction with hydrogen $\left(\mathrm{H}_{2}-\mathrm{TPR}\right)$, Temperature-programmed desorption with $\mathrm{NH}_{3}\left(\mathrm{NH}_{3}\right.$-TPD), X-Ray Diffraction (XRD), and Transmission Electron Microscopy (TEM). The results show that the SBA-15 supported catalyst exhibits higher $\mathrm{C}_{6}-\mathrm{C}_{12}$ selectivity $(57.5 \%)$, and MA supported catalyst facilitates the formation of higher hydrocarbons $\left(\mathrm{C}_{13}-\mathrm{C}_{20}\right)$ having a selectivity of $46.7 \%$. This study attributes the use of both the support materials for the production of liquid hydrocarbons through FT synthesis.
\end{abstract}

\section{Introduction}

Skyrocketing energy demand for enhancement of human lifestyle, development of industries, and transportation sectors across the globe is a matter of great concern, especially the markets for specified liquid fuels like gasoline, jet, and diesel [1]. It is a challenging and demanding task to develop alternative and environmentally friendly routes to produce liquid fuel. Fischer-Tropsch (FT) synthesis and associated technologies like Gas-To-Liquid (GTL), Coal-To-Liquid (CTL) and Biomass-To-Liquid (BTL) routes are a promising alternative for the production of substitutes of petroleum crude. They can positively contribute to the world energy security and supplies. Although FT was discovered about a century before, still it is an attractive and alternative source of environmentally benign liquid hydrocarbon fuels with near-zero sulfur and aromatic compounds. FT synthesis is a catalytic reaction in which syngas (a mixture of $\mathrm{CO}$ and $\mathrm{H}_{2}$ ) is converted to liquid hydrocarbon fuels $[2,3]$. FT synthesis has received considerable worldwide attention in both industrial as well as in academic domains. Catalyst is considered as the heart of this process. Preparation technique, the composition of the catalyst, and other operating parameters like temperature, pressure, etc. play crucial roles towards FT synthesis, activity of the catalyst,

\footnotetext{
* Corresponding author: sudip_maity@yahoo.com
}

and product distribution. So, the development of FT catalysts with higher activity, selectivity, and stability is of utmost importance for better performance. Among the transition metals, ruthenium, nickel, cobalt and iron are the most common metals used for FT catalyst. Cobalt is an active metal for the synthesis of long-chain hydrocarbons due to its high activity and selectivity towards paraffins, low Water-Gas Shift (WGS) activity, lower $\mathrm{CO}_{2}$ selectivity, and less oxygenates formation [4-6]. Many researchers have studied the effect of different oxide supports (titania, silica, alumina, zirconia, etc.) on the activity/selectivity of Co catalysts $[7,8]$, and these supports have considerable influence on the dispersion and reducibility of active metal as well. $\mathrm{Al}_{2} \mathrm{O}_{3}, \mathrm{SiO}_{2}$ ' and $\mathrm{TiO}_{2}$ are the most extensively used support materials for $\mathrm{Co}$ catalysts. In $\mathrm{Co} / \mathrm{Al}_{2} \mathrm{O}_{3}$ catalyst, the limited reducibility of $\mathrm{Co}$ is due to the strong interaction between the support and the Co [9-11]. Due to the weaker interaction with silica, dispersion of $\mathrm{Co}$ is low, enhancing the reducibility of Co oxides. Reducibility of cobalt plays a vital role in catalytic activity of the supported catalyst. Promoters such as Pd, Pt, Re, and Ru are added to the Co catalysts to facilitate better reduction of Co as it has strong interaction with $\mathrm{Al}_{2} \mathrm{O}_{3}$ than other supports [12, 13]. It is reported by many researchers that $\mathrm{Pd}$ promoter enhances adsorption sites for $\mathrm{H}_{2}$ on Co catalyst and thus increasing the hydrogenation rate in FT synthesis [14-16]. Guczi et al. [17] showed that $\mathrm{Pd}$ as a promoter to 
$\mathrm{Co} / \mathrm{SiO}_{2}$ increased the relative fraction of alkanes in FT synthesis reaction. Many researchers utilized Pd to improve the performance of zeolite and FT synthesis hybrid catalysts for $\mathrm{C}_{5}-\mathrm{C}_{11}$ iso-paraffins synthesis $[18,19]$. Researchers of the Centre for Applied Energy Research (CAER), UK [20], observed that $\mathrm{Pd}$ is an effective promoter of cobalt oxide reduction in $\mathrm{Co} / \gamma-\mathrm{Al}_{2} \mathrm{O}_{3} \mathrm{FT}$ catalysts. Pd can improve the reduction and dispersion of cobalt-based FT synthesis catalysts [21]. Among bimetallic catalysts, Co-Pd systems are of high interest for several reactions, such as hydrogenation reactions [22] and FT synthesis [23, 24]. Furthermore, the presence of $\mathrm{Pd}$ can prevent the formation of hard wax which causes catalyst deactivation [25]. It is observed that $\mathrm{Pd}$ promoter produces a variety of effects on the structure of cobalt catalysts which modifications could affect cobalt reducibility and/or cobalt dispersion, formation of bimetallic particles, and formation of barely reducible cobalt support mixed compounds [23-25].

In this research paper, the role of $\mathrm{Pd}$ promotion on SBA-15 and MA supported cobalt catalysts is systematically evaluated for liquid hydrocarbon synthesis from syngas $\left(\mathrm{CO}+\mathrm{H}_{2}\right)$. Catalytic performance including $\mathrm{CO}$ conversion and selectivity of the catalysts has been evaluated under similar conditions in a fixed bed tubular reactor. The effects of catalysts on FT product spectrum have also been studied using chain growth probability $(\alpha)$ of Anderson-Schulz-Flory (ASF) equation.

\section{Experimental}

All chemicals for this work are of commercial grade and used without any purification. The used chemicals are Tetraethyl Orthosilicate (TEOS, Merck), Cetyltrimethyl Ammonium Bromide (CTAB, Sigma-Aldrich), Pluronic P-123 (M.W. 5800, Sigma-Aldrich), Hydrochloric acid (Merck), Cobalt nitrate hexahydrate (Merck), Aluminum nitrate (Merck) and Palladium chloride (S.D. Fine-Chem $L t d$.).

\subsection{Preparation of Mesoporous Alumina (MA)}

Mesoporous Alumina is synthesized through hydrothermal technique with molar compositions of 1.0 Al:0.5 CTAB:5.28 Urea:70 $\mathrm{H}_{2} \mathrm{O}$ [26]. In this synthesis process, $74 \mathrm{~g}$ of $\mathrm{Al}$ $\left(\mathrm{NO}_{3}\right)_{3} \cdot 9 \mathrm{H}_{2} \mathrm{O}$ and $62.15 \mathrm{~g}$ of urea are dissolved in $550 \mathrm{~mL}$ of de-ionized water and stirred vigorously for $30 \mathrm{~min}$ at $35{ }^{\circ} \mathrm{C}$ and then $35.75 \mathrm{~g}$ of CTAB is added to the solution with continued stirring till homogeneous solution is formed. Thereafter, mixture is poured into a Teflon autoclave bottle and heated at $120{ }^{\circ} \mathrm{C}$ for $24 \mathrm{~h}$. The white precipitate thus obtained is filtered using Whatman filter paper and washed with deionised water. Finally, the sample is dried at $120{ }^{\circ} \mathrm{C}$ in an air oven for $12 \mathrm{~h}$ and calcined at $750{ }^{\circ} \mathrm{C} @ 5^{\circ} \mathrm{C} / \mathrm{min}$ for $5 \mathrm{~h}$.

\subsection{Preparation of SBA-15}

The SBA-15 is synthesized using the method as reported by Ding et al. [27]. In this synthesis process, $16 \mathrm{~g}$ Pluronic (P-123), $576 \mathrm{~mL}$ deionised water and $18.3 \mathrm{~mL}$ concentrated
$\mathrm{HCl}(35$ wt.\%) are taken in a beaker and stirred continuously until P-123 is fully dissolved. As and when the solution becomes homogeneous, $35.74 \mathrm{~mL}$ Tetraethyl Orthosilicate (TEOS) is added to it and stirred continuously for $24 \mathrm{~h}$ at $35{ }^{\circ} \mathrm{C}$ temperature. The mixture is then transferred to a polypropylene bottle and it is kept under static condition for $24 \mathrm{~h}$ at $100{ }^{\circ} \mathrm{C}$ in an air oven. The resulting precipitate is filtered by using Whatman (No. 42) filter paper, washed with deionised water and dried at $80^{\circ} \mathrm{C}$ for $16 \mathrm{~h}$ and then calcined at $540{ }^{\circ} \mathrm{C} @ 1{ }^{\circ} \mathrm{C} / \min$ for $16 \mathrm{~h}$. The prepared sample is kept in a desiccator.

\subsection{Preparation of Co-Pd/MA and Co-Pd/SBA-15 catalysts}

The catalysts are prepared by co-impregnating the supports (MA and SBA-15) with an aqueous solution of $\mathrm{Co}$ $\left(\mathrm{NO}_{3}\right)_{2} \cdot 6 \mathrm{H}_{2} \mathrm{O}$ and $\mathrm{PdCl}_{2}$. The catalysts are named as $\mathrm{Co}^{-}$ $\mathrm{Pd} / \mathrm{MA}$ (Pd promoted mesoporous alumina supported Co catalyst) and Co-Pd/SBA-15 (Pd promoted SBA-15 supported Co catalyst). The cobalt and palladium loading are fixed at 15 wt.\% and 0.1 wt.\%, respectively. The impregnated samples are dried at $100{ }^{\circ} \mathrm{C}$ for $12 \mathrm{~h}$, and then calcined at $350{ }^{\circ} \mathrm{C}$ for $6 \mathrm{~h}$ according to heat input of $30{ }^{\circ} \mathrm{C}-$ $200{ }^{\circ} \mathrm{C} @ 2{ }^{\circ} \mathrm{C} / \mathrm{min}$, and $200{ }^{\circ} \mathrm{C}-350{ }^{\circ} \mathrm{C} @ 1{ }^{\circ} \mathrm{C} / \mathrm{min}$ (hold for $5 \mathrm{~h})$.

\section{Characterization}

Brunauer-Emmett-Teller (BET) surface area measurements are performed in a Micromeritics TriStar 3000 instrument by $\mathrm{N}_{2}$ adsorption-desorption isotherms. Pore volumes and average pore diameter of the catalysts are also measured with the same instrument. SAXS (Small Angle X-ray Scattering) and WAXRD (Wide Angle X-Ray Diffraction) patterns are recorded using a Rigaku Smartlab instrument. The phases of the fresh calcined catalysts are analyzed and crystallite size of $\mathrm{Co}_{3} \mathrm{O}_{4}$ is determined from the XRD pattern using Scherrer equation mentioned below:

$$
d=0.9 \lambda / \beta \operatorname{Cos} \theta,
$$

where, $d$ is the average crystallite size, $\lambda$ is the wavelength of the X-ray, $\beta$ is the Full Width at Half Maximum (FWHM) due to crystallite size broadening and $\theta$ is the position of strongest Bragg profile in the diffractogram.

Catalysts are also analyzed using Transmission Electron Microscopy (TEM) (JEOL, JEM 2100 instrument) to study the morphology. The Temperature-Programmed Reduction (TPR), and Temperature-Programmed Desorption (TPD) profiles of the catalysts are measured by using ChemiSorb 2720 (Micrometrics, USA) instrument equipped with a Thermal Conductivity Detector (TCD). The temperatureprogrammed reduction profiles are determined with the flow $10 \% \mathrm{H}_{2}$ in $\mathrm{Ar}$ at a flow rate of $20 \mathrm{~mL} / \mathrm{min}$ and the temperature is increased linearly from room temperature to $1000{ }^{\circ} \mathrm{C} @$ rate of $10{ }^{\circ} \mathrm{C} / \mathrm{min}$. Prior to analysis, $0.1-0.2 \mathrm{~g}$ of calcined catalyst is taken in a U-tube quartz reactor and dried at $150{ }^{\circ} \mathrm{C}$ for $2 \mathrm{~h}$ under flow of Argon gas at $20 \mathrm{~mL} / \mathrm{min}$. The temperature-programmed desorption of 


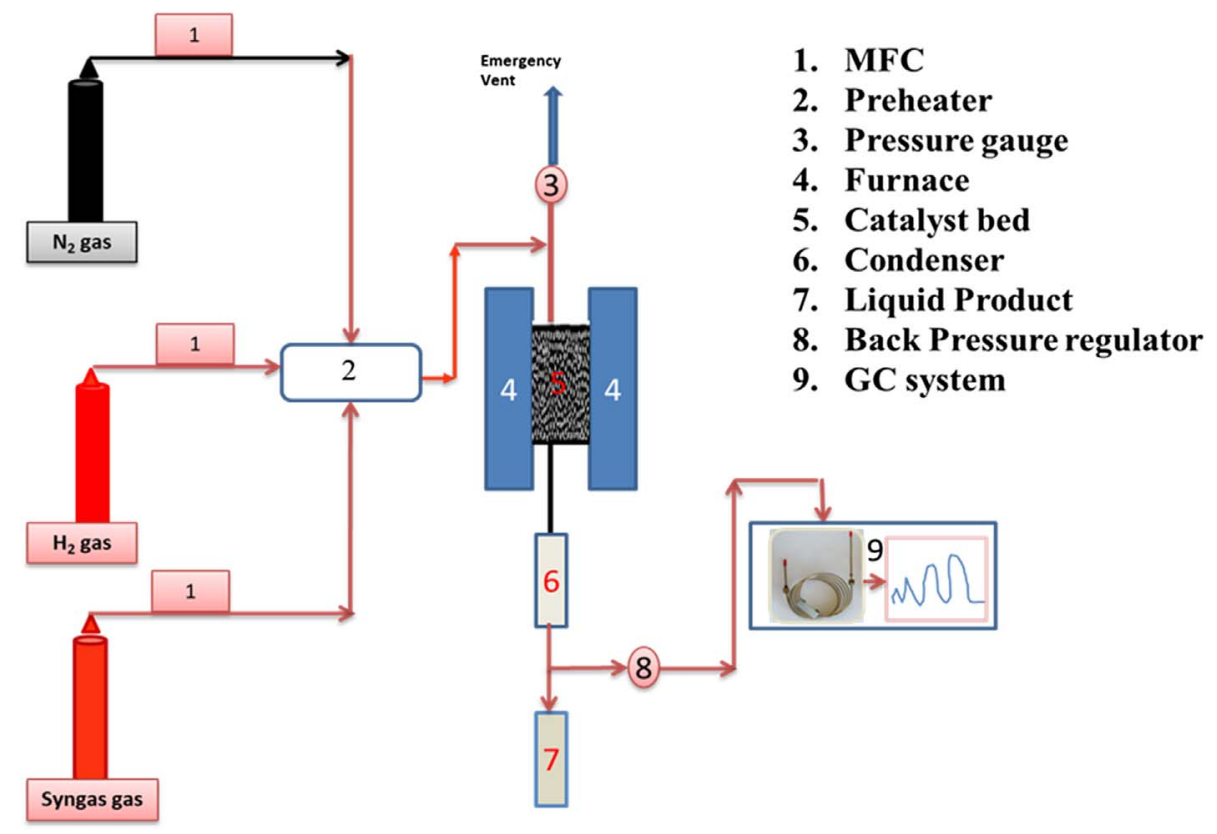

Fig. 1. Schematic representation of fixed bed reactor.

Table 1. Experimental conditions for evaluation of catalyst activity.

\begin{tabular}{|c|c|c|c|c|c|}
\hline \multicolumn{3}{|c|}{ Reduction } & \multicolumn{3}{|c|}{ Performance evaluation } \\
\hline Temp $\left({ }^{\circ} \mathrm{C}\right)$ & GHSV & Reducing gas & Temp $\left({ }^{\circ} \mathrm{C}\right)$ & Pressure & GHSV \\
\hline 350 & $400 \mathrm{~h}^{-1}$ & $\mathrm{H}_{2}$ & 220 & 30 bar & $500 \mathrm{~h}^{-1}$ \\
\hline
\end{tabular}

the catalysts is measured by passing $\mathrm{NH}_{3}\left(0.4 \% \mathrm{NH}_{3}\right.$ in $\left.\mathrm{He}\right)$ over the catalysts at room temperature for $30 \mathrm{~min}$. Then adsorbed gas is desorbed in the flow of $\mathrm{He} @$ ate of $20 \mathrm{~mL} / \mathrm{min}$ and temperature is increased from room temperature to $1000{ }^{\circ} \mathrm{C}$ at a rate of $10^{\circ} \mathrm{C} / \mathrm{min}$.

The FT experiments are performed in a fixed-bed stainless steel reactor (internal diameter: $10 \mathrm{~mm}$, Volume: $10 \mathrm{~mL}$ ). The schematic diagram of the reactor set up is shown in Figure 1 and experimental parameter is mentioned in Table $1.3 .0 \mathrm{~mL}$ powder calcined catalyst is charged in the reactor. Activity of the catalysts is evaluated at pressure of 30 bar and GHSV of $500 \mathrm{~h}^{-1}$. The catalysts are reduced $i n$ situ with $\mathrm{H}_{2}$ flow (GHSV of $400 \mathrm{~h}^{-1}$ ) at temperature $350{ }^{\circ} \mathrm{C}$ for $12 \mathrm{~h}$. After reduction, the temperature is lowered to $180{ }^{\circ} \mathrm{C}$ under the flow of $\mathrm{H}_{2}$, the gas flow is switched to syngas $\left(\mathrm{H}_{2}: 28.63 \%, \mathrm{~N}_{2}: 46.83 \%\right.$, CO: $14.27 \%, \mathrm{CO}_{2}: 9.27 \%$ and $\mathrm{CH}_{4}: 0.997 \%, \mathrm{H}_{2} / \mathrm{CO}: 2$, GHSV: $500 \mathrm{~h}^{-1}$ ) with simultaneous increase of temperature up to $220{ }^{\circ} \mathrm{C}$ with an increment of $5{ }^{\circ} \mathrm{C} / \mathrm{min}$. The flow of all the gases is controlled independently by mass flow controllers (Brooks). During testing of Fischer-Tropsch activity, the condensed vapors are collected in bottom catch pot. The uncondensed gas mixture is continuously monitored by GC (Model-GC 1000; Make: $\mathrm{M} / \mathrm{s}$ Chemito Technologies Ltd, India) equipped with TCD and FID detectors.

\section{Results and discussion}

\section{1 $\mathrm{N}_{2}$ adsorption-desorption isotherm}

The adsorption-desorption isotherms of both the catalysts and support materials are shown in Figures 2 and 3, respectively. $\mathrm{N}_{2}$ adsorption-desorption isotherms of both the support materials as well as catalysts showed hysteresis characteristics of Type IV, indicating formation of mesoporous structures according to IUPAC classification [28]. BET surface area and pore size of catalysts are presented in Table 2. The surface areas of the catalysts are decreased by $28 \%$ and $30 \%$ respectively after Co impregnation for $\mathrm{Co}-\mathrm{Pd} / \mathrm{MA}$ and $\mathrm{Co}-\mathrm{Pd} / \mathrm{SBA}-15$ catalysts. Correspondingly, the pore volume and the pore diameter have also decreased by $45 \%$ and $24 \%$ respectively for both the catalysts. The sharp decrease in the BET surface area and total pore volume is due to impregnation of Co and $\mathrm{Pd}$ into the mesoporous supports indicating that a portion of the metal oxide particles have entered into the pores and at the mouths of the supports leading to partial blockage by formation of agglomerates [29]. The Pore Size Distribution (PSD) study of the catalysts shows that $\mathrm{Co}-\mathrm{Pd} / \mathrm{MA}$ has wider and larger pore diameter as compared to $\mathrm{Co}-\mathrm{Pd} /$ SBA-15. 

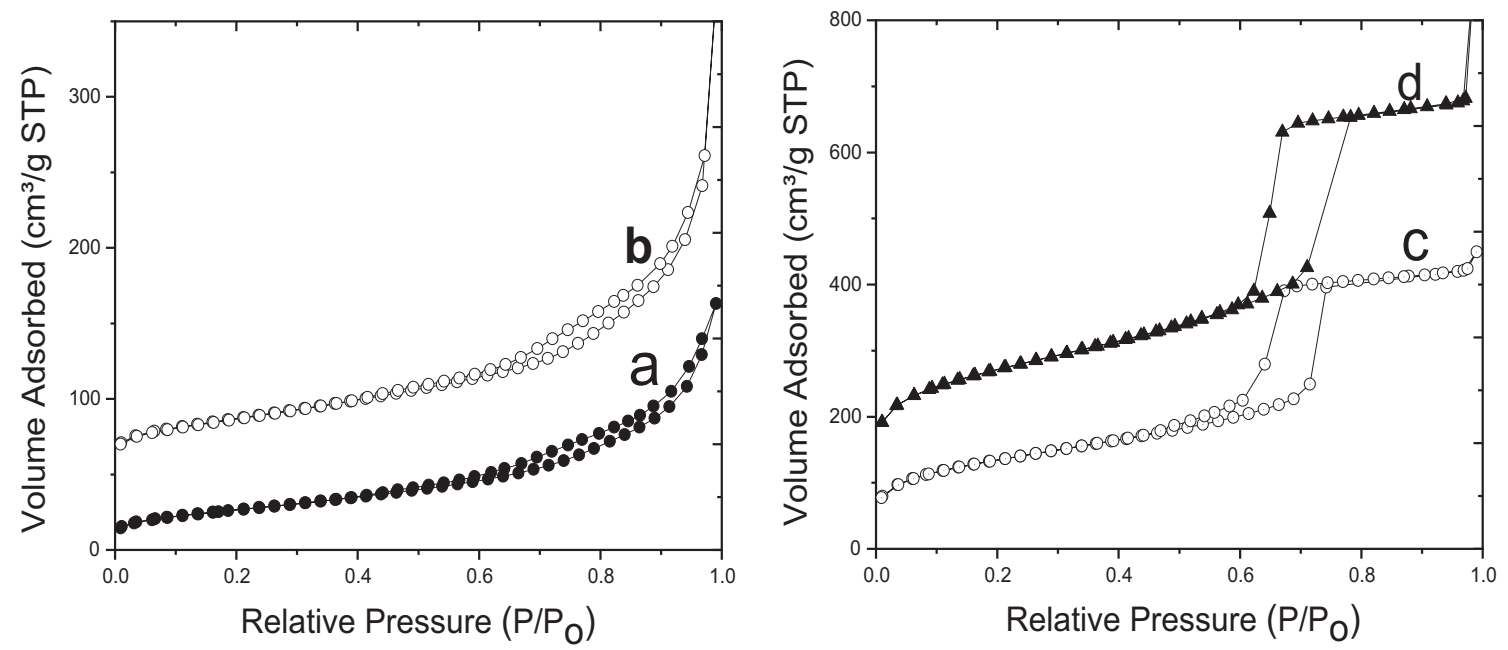

Fig. 2. $\mathrm{N}_{2}$ adsorption-desorption isotherms of (a) MA, (b) Co-Pd/MA, (c) SBA-15, and (d) Co-Pd/SBA-15.
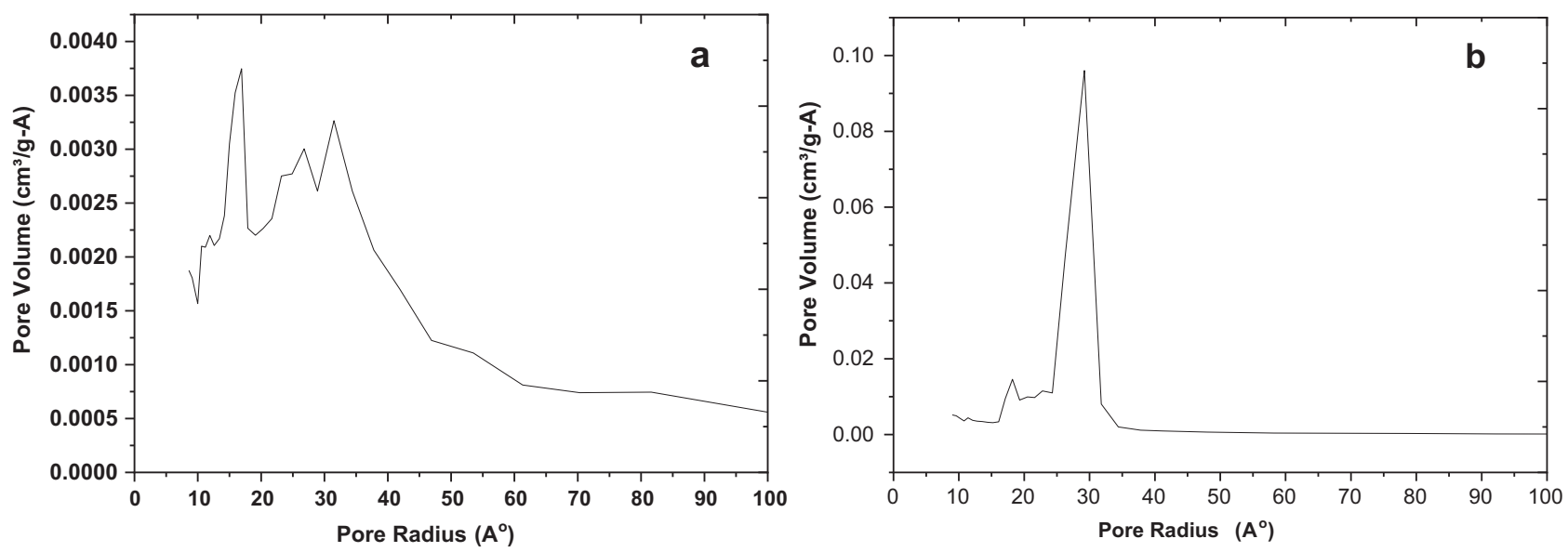

Fig. 3. Pore size distribution of (a) $\mathrm{Co}-\mathrm{Pd} / \mathrm{MA}$, (b) $\mathrm{Co}-\mathrm{Pd} / \mathrm{SBA}-15$.

Table 2. Surface area of the mesoporous supports and catalysts.

\begin{tabular}{lccc}
\hline Catalyst & Surface area $\left(\mathrm{m}^{2} / \mathrm{g}\right)$ & Pore size $(\mathrm{nm})$ & Pore volume $\left(\mathrm{cm}^{3} / \mathrm{g}\right)$ \\
\hline Mesoporous Alumina (MA) & 135 & 13.8 & 0.46 \\
Co-Pd/MA & 96 & 10.4 & 0.252 \\
SBA-15 & 663 & 7.6 & 1.28 \\
Co-Pd/SBA-15 & 458 & 5.8 & 0.695 \\
\hline
\end{tabular}

\subsection{X-Ray Diffraction (XRD)}

The SAXS patterns of MA and SBA-15 (Fig. 4) show no peak for MA, whereas SBA-15 shows one peak between 0.5 and $3^{\circ}$ [30]. This indicates that the MA has different morphology. The MA and $\mathrm{Co}-\mathrm{Pd} / \mathrm{MA}$ are characterized by wide angle X-ray diffraction as shown in Figure 5. The peaks appeared at $2 \theta$ values $31.94^{\circ}, 37.6^{\circ}, 45.79^{\circ}, 60.09^{\circ}$, $66.76^{\circ}$ and $85.02^{\circ}$ that correspond to the characteristic reflections of (220), (311), (400), (511), (440) and (444) planes of the cubic $\gamma-\mathrm{Al}_{2} \mathrm{O}_{3}$ structure with reference to the JCPDS Card no. 00-002-1420. The XRD patterns of Co$\mathrm{Pd} / \mathrm{MA}$ catalyst showed various peaks at $2 \theta$ of $31.35^{\circ}$, $36.88^{\circ}, 45.64^{\circ}, 59.3^{\circ}, 65.27^{\circ}$ and $77.92^{\circ}$ respectively, that correspond to the characteristic reflections of (220), (311), (400), (511), (440) and (533) planes of $\mathrm{Co}_{3} \mathrm{O}_{4}$ with reference to the JCPDS Card no. 00-009-0418. The SAXS pattern of SBA-15 mainly displayed reflections at $2 \theta$ of $0.98^{\circ}$ that explains characteristics of the hexagonal structure as reported by other researchers [31, 32]. The wide angle 

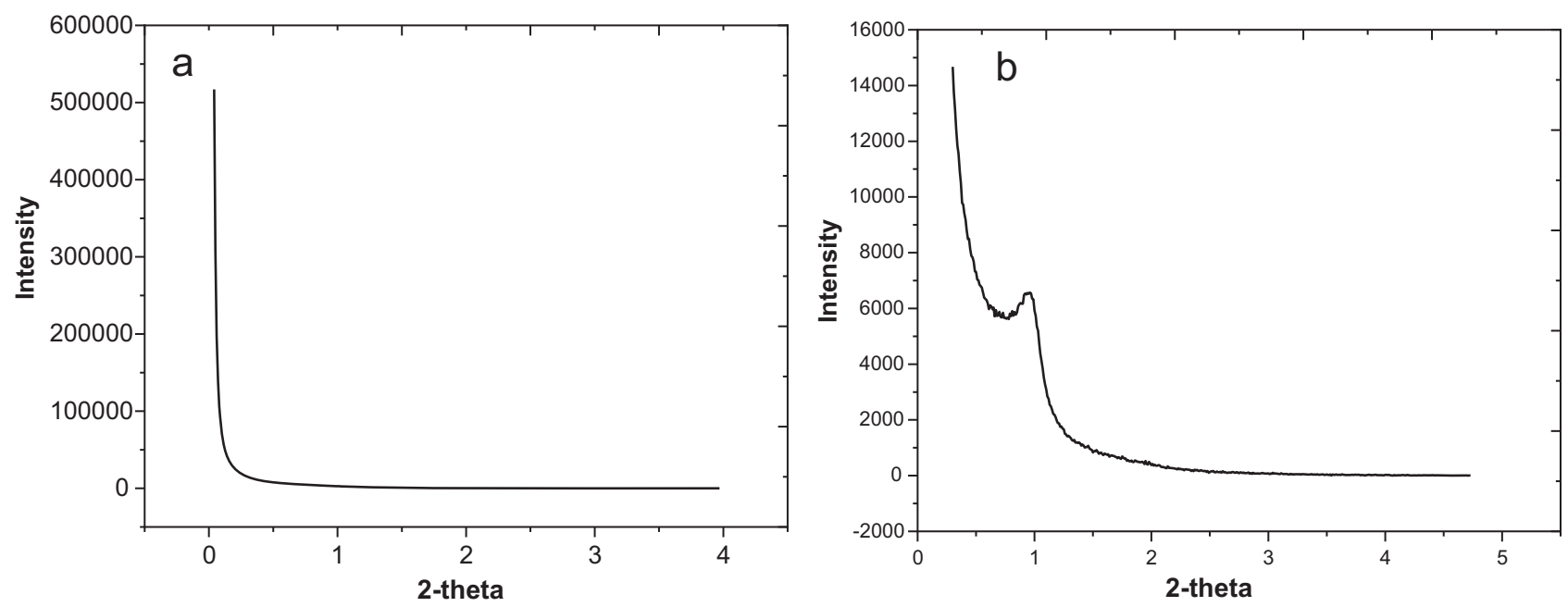

Fig. 4. SAXS pattern of (a) MA, and (b) SBA-15.
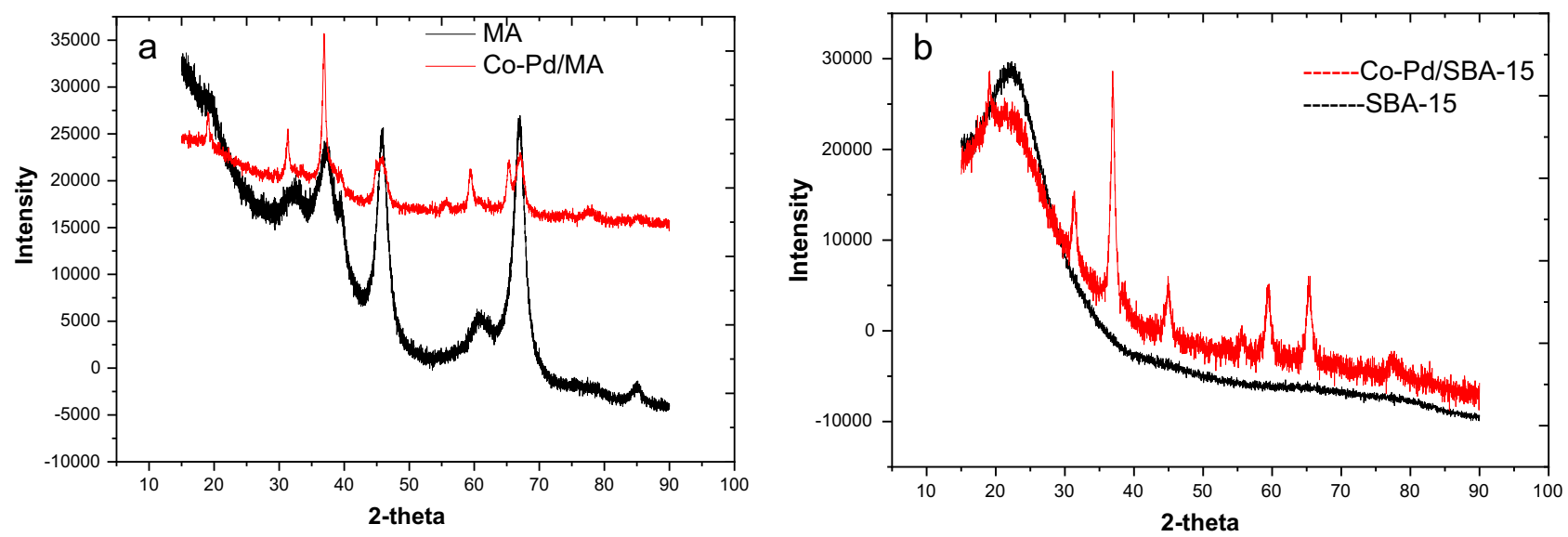

Fig. 5. XRD patterns of (a) MA, Co-Pd/MA, (b) SBA-15, Co-Pd/SBA-15 catalysts showing the peaks of $\mathrm{Co}_{3} \mathrm{O}_{4}$.

Table 3. Crystallite size of the catalysts.

\begin{tabular}{lcc}
\hline Catalyst & $\begin{array}{c}\text { Crystallite size by } \\
\text { XRD }(\mathrm{nm})\end{array}$ & $\begin{array}{c}\text { Crystallite size by } \\
\text { TEM }(\mathrm{nm})\end{array}$ \\
\hline Co-Pd/MA & 16.8 & 18.28 \\
Co-Pd/ & 10.25 & 8.28 \\
SBA-15 & & \\
\hline
\end{tabular}

X-ray diffraction of SBA-15 (Fig. 5) shows a broad peak around $2 \theta$ value of $21.98^{\circ}$ indicated as compared with the JCPDS Card no. 00-001-0438. The wide angle X-ray diffraction pattern of catalyst $\mathrm{Co}-\mathrm{Pd} / \mathrm{SBA}-15$ with peaks at $2 \theta$ of $31.35^{\circ}, 36.88^{\circ}, 45.64^{\circ}, 55.64^{\circ}, 59.3^{\circ}, 65.27^{\circ}$ and $77.68^{\circ}$ that correspond to the characteristic reflections of (220), (311), (400), (422), (511), (440) and (533) planes of the cubic $\mathrm{Co}_{3} \mathrm{O}_{4}$ (JCPDS Card no. 00-009-0418) structure [33]. However, there is no peak for Pd oxide in both the catalyst due to very low content of $\mathrm{Pd}[15,34]$. Scherrer equation is used to calculate the crystallite size of $\mathrm{Co}_{3} \mathrm{O}_{4}$ at $2 \theta$ of $36.94^{\circ}$ in both the catalysts and results are presented in
Table 3. The crystal sizes thus determined through XRD technique and from TEM study (Tab. 3, Fig. 6) of the catalysts are similar. It is noted that the $\mathrm{Co}_{3} \mathrm{O}_{4}$ crystallite size (Tab. 3) is larger than the average pore diameter of the Co$\mathrm{Pd} / \mathrm{MA}$ and $\mathrm{Co}-\mathrm{Pd} / \mathrm{SBA}-15$ catalysts (Tab. 2), which indicates that some portions of $\mathrm{Co}_{3} \mathrm{O}_{4}$ particles are present on the mouth of the pores.

\subsection{Temperature-Programmed Reduction (TPR)}

TPR profiles of $\mathrm{Co}-\mathrm{Pd} / \mathrm{MA}$ and $\mathrm{Co}-\mathrm{Pd} / \mathrm{SBA}-15$ catalysts are shown in Figure 7. In Co-Pd/MA catalyst, the two peaks are observed at $178{ }^{\circ} \mathrm{C}$ and $300{ }^{\circ} \mathrm{C}$ that correspond to the two-step reduction. The first peak is attributed to the reduction of $\mathrm{Co}_{3} \mathrm{O}_{4}$ to $\mathrm{CoO}$ and the second peak signifies the reduction of the $\mathrm{CoO}$ to Co. Hossain [35] observed reduction profile of $\mathrm{Co} / \mathrm{Al}_{2} \mathrm{O}_{3}$ catalyst (without Pd promotion) where the reduction completed in two steps; firstly, $\mathrm{Co}_{3} \mathrm{O}_{4}$ to $\mathrm{CoO}$ and then $\mathrm{CoO}$ to $\mathrm{Co}$ in temperature range of $300-400{ }^{\circ} \mathrm{C}$ and $400-600{ }^{\circ} \mathrm{C}$ respectively. Khodakov et al. [36] observed peaks at $600{ }^{\circ} \mathrm{C}$ and higher 

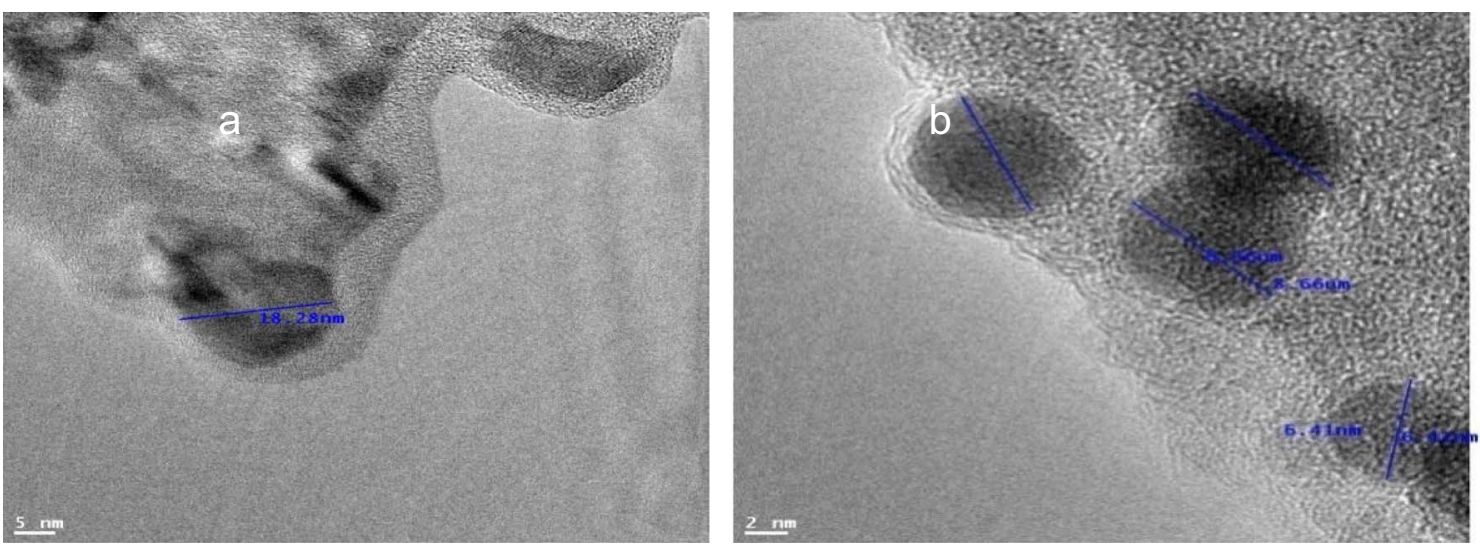

Fig. 6. TEM images of (a) Co-Pd/MA, and (b) $\mathrm{Co}-\mathrm{Pd} / \mathrm{SBA}-15$.

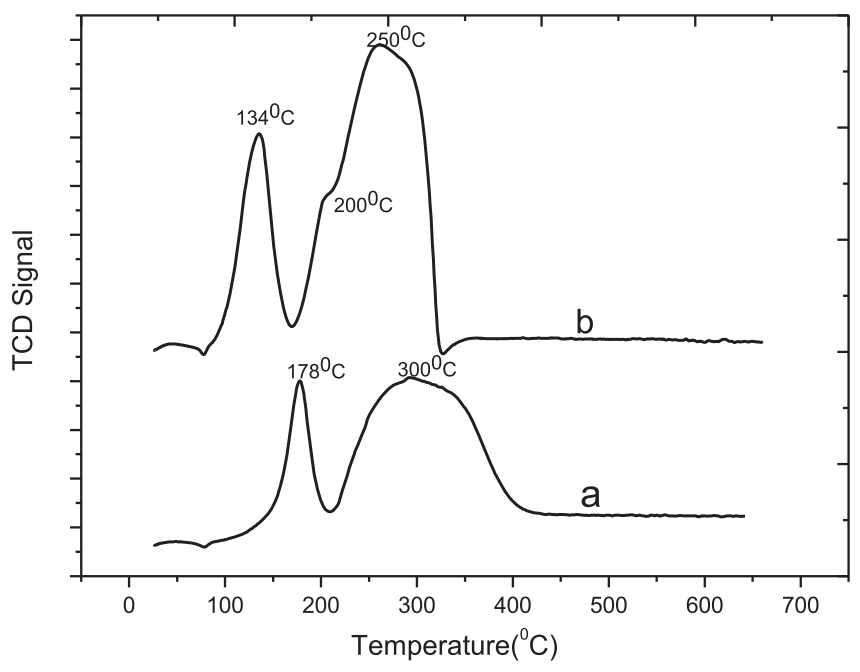

Fig. 7. $\mathrm{H}_{2}-\mathrm{TPR}$ profiles of the catalyst (a) $\mathrm{Co}-\mathrm{Pd} / \mathrm{MA}$, and (b) $\mathrm{Co}-\mathrm{Pd} / \mathrm{SBA}-15$.

temperature refers to reduction of Co species such as cobalt aluminate. The reduction peaks observed for $\mathrm{Co}-\mathrm{Pd} / \mathrm{SBA}-$ 15 catalyst are at lower temperature than that of $\mathrm{Co}-\mathrm{Pd} /$ MA. Three reduction peaks are observed for $\mathrm{Co}-\mathrm{Pd} /$ SBA- 15 catalysts. The TPR profile of $\mathrm{Co}-\mathrm{Pd} / \mathrm{SBA}-15$ catalyst shows high intensity peaks at lower temperature, indicating its higher reducibility. The TPR profile of $\mathrm{Co}-\mathrm{Pd} /$ SBA-15, consists of three peaks at $134{ }^{\circ} \mathrm{C}, 200{ }^{\circ} \mathrm{C}$ and $250{ }^{\circ} \mathrm{C}$, corresponding to the reduction of $\mathrm{Co}_{3} \mathrm{O}_{4}$ to $\mathrm{CoO}$, smaller particle size of $\mathrm{Co}_{3} \mathrm{O}_{4}$ to $\mathrm{CoO}$ and $\mathrm{CoO}$ to $\mathrm{Co}$ [37]. Yuanyuan et al. [38] interpreted the first peak at $305{ }^{\circ} \mathrm{C}$ to the reduction of $\mathrm{Co}_{3} \mathrm{O} 4$ to $\mathrm{CoO}$, second peak at $442{ }^{\circ} \mathrm{C}$ to subsequent reduction of $\mathrm{CoO}$ to $\mathrm{Co}$ for the TPR profile of $\mathrm{Co} / \mathrm{SBA}-15$ (without $\mathrm{Pd}$ promotion) catalyst. In another study, the broad peak at higher temperature $626{ }^{\circ} \mathrm{C}$ is assigned to the reduction of cobalt silicate $\left(\mathrm{Co}_{2} \mathrm{SiO}_{4}\right)$ formed by a strong interaction between cobalt and the support $[39,40]$. However, in present work the reduction peak above $400{ }^{\circ} \mathrm{C}$ is not observed, signifying enhancement of reducibility by $\mathrm{Pd}$ promotion [41].

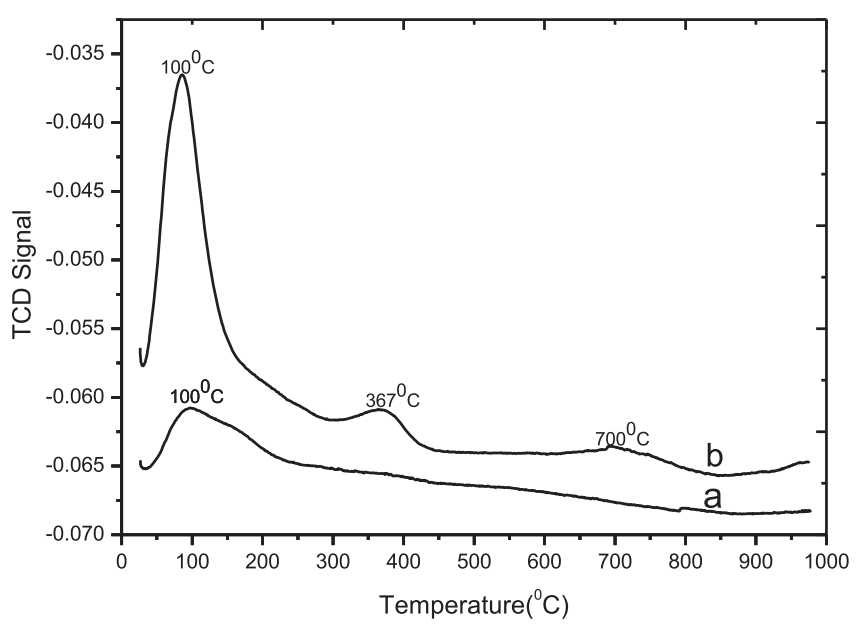

Fig. 8. $\mathrm{NH}_{3}-\mathrm{TPD}$ profiles of (a) $\mathrm{Co}-\mathrm{Pd} / \mathrm{SBA}-15$, and (b) $\mathrm{Co}-\mathrm{Pd} / \mathrm{MA}$.

\subsection{Temperature-Programmed Desorption (TPD)}

The quantity and strength of acidic sites of the catalyst are measured by $\mathrm{NH}_{3}$-TPD (Fig. 8). $\mathrm{NH}_{3}$ desorption peak at $100{ }^{\circ} \mathrm{C}$ and very small peaks at high temperature $367^{\circ} \mathrm{C}$ and $700{ }^{\circ} \mathrm{C}$ are observed for $\mathrm{Co}-\mathrm{Pd} / \mathrm{MA}$ catalyst. The $\mathrm{Co}-\mathrm{Pd} / \mathrm{SBA}-15$ shows the peak at $90^{\circ} \mathrm{C}$, owning to desorption of the physisorbed $\mathrm{NH}_{3}$ from the $\mathrm{Si}-\mathrm{OH}$ sites (weak acid sites) of $\mathrm{SBA}-15$ [42]. The $\mathrm{Co}-\mathrm{Pd} / \mathrm{SBA}-15$ catalyst contains more week acid sites however $\mathrm{Co}-\mathrm{Pd} / \mathrm{MA}$ catalyst contains more strong acid sites (Tab. 4).

\subsection{FT products distribution}

The catalytic performance of both catalysts are investigated for Low Temperature Fischer-Tropsch (LTFT) synthesis at pressure 30 bar and temperature $220{ }^{\circ} \mathrm{C}$ using syngas. The characterization of the liquid products is done by Simdist Analyser GC $(M / s$ Thermo Scientific TRACE 1110 $\mathrm{GC})$. The carbon number distribution of $\mathrm{C}_{5+}$ hydrocarbons (mole \%) for each catalyst is presented in Figures 9 and 10. 
Table 4. Amount of ammonia desorbed at different temperature.

\begin{tabular}{lccc}
\hline Catalyst & $\begin{array}{c}\text { Amount } \\
\text { of } \mathrm{NH}_{3} \text { adsorbed } \\
(\mu \mathrm{mol} / \mathrm{g} \text { sample })\end{array}$ & Temperature $\left({ }^{\circ} \mathrm{C}\right)$ \\
\hline $\mathrm{Co}-\mathrm{Pd} / \mathrm{SBA}-15$ & Weak & 79 & 100 \\
$\mathrm{Co}-\mathrm{Pd} / \mathrm{MA}$ & Weak & 198 & 90 \\
& Medium & 22 & 367 \\
& Strong & 11 & 700 \\
\hline
\end{tabular}

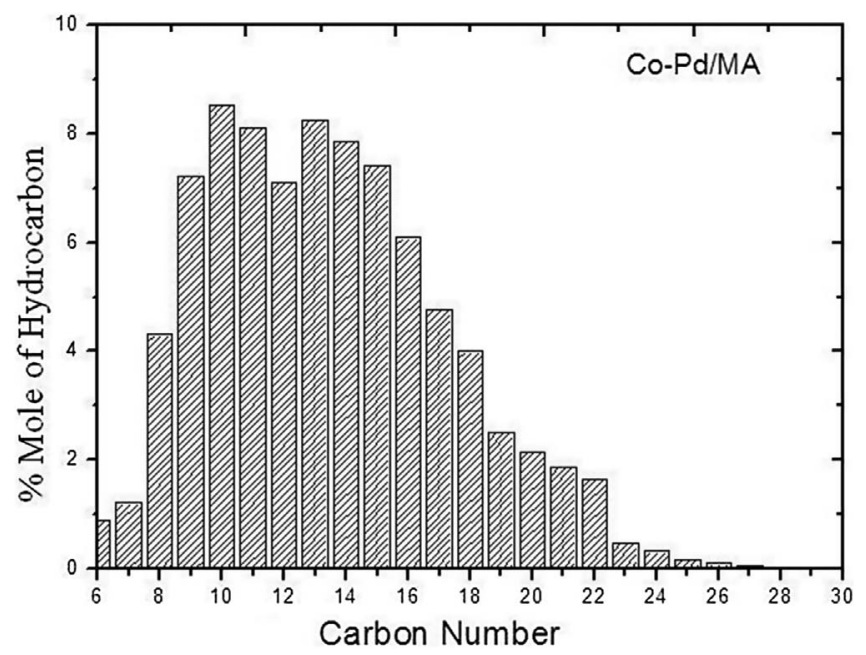

Fig. 9. Distribution of carbon-containing species over $\mathrm{Co}-\mathrm{Pd} /$ MA under FT reaction conditions.

The catalytic activities of the catalysts are summarized in (Tab. 5) which shows that Co-Pd/SBA-15 catalyst is having higher selectivity towards lower hydrocarbons (Gasoline range hydrocarbon, $\sim 57.5 \%$ ), in contrast to the $\mathrm{Co}-\mathrm{Pd} / \mathrm{MA}$ catalyst which shows higher hydrocarbons selectivity (Diesel range hydrocarbon, $\sim 46.7 \%$ ). Present study reveals that the total $\mathrm{C}_{5+}$ hydrocarbon for both catalysts namely $\mathrm{Co}-\mathrm{Pd} / \mathrm{MA}$ and $\mathrm{Co}-\mathrm{Pd} / \mathrm{SBA}-15$ are $85 \%$ and $72.6 \%$, respectively. While, A. Jean-Marie et al. [43] observed $77 \% \mathrm{C}_{5+}$ hydrocarbon selectivity and $22 \% \mathrm{CO}$ conversion using $15 \mathrm{Co} / \mathrm{Al}_{2} \mathrm{O}_{3}$ catalyst. Also, $\mathrm{Mu}$ et al. [44] reported $82.4 \%$ selectivity towards $\mathrm{C}_{5+}$ hydrocarbon and $58.7 \%$ CO conversion using SBA-15 supported 15 wt.\% cobalt catalyst. So, it may be inferred that Pd promotion enhances

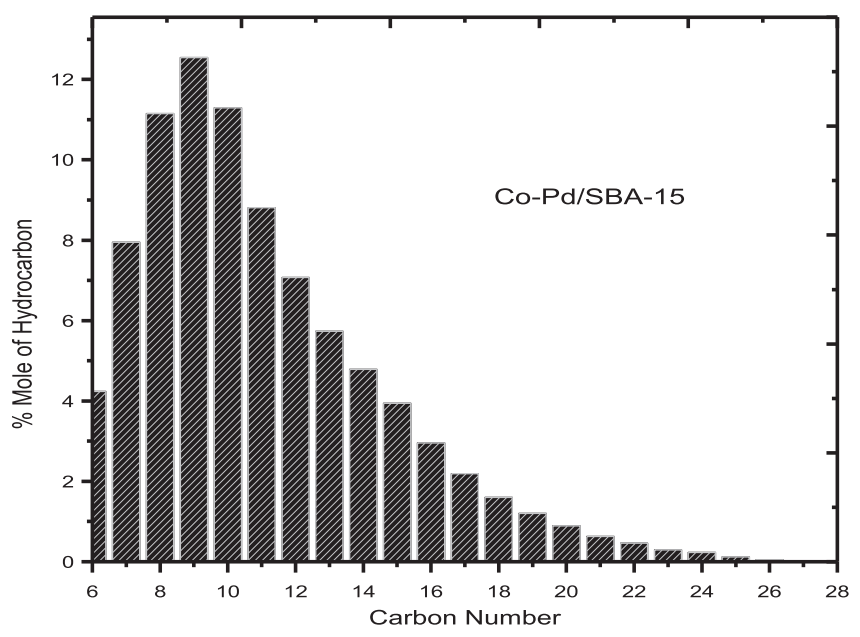

Fig. 10. Distribution of carbon-containing species over $\mathrm{Co}-\mathrm{Pd} /$ SBA-15 under FT reaction conditions.

the reducibility of $\mathrm{Co}$ - catalyst, increasing $\mathrm{CO}$ conversion in FTS. The difference in the nature of FT product distribution is associated with the variation in the acidic strength of the supports MA and SBA-15. MA being more acidic compared to SBA-15, responsible for the cracking of heavy hydrocarbons [45]. The conversion of syngas is higher for Co-Pd/MA catalyst, but selectivity towards the middle distillate product is higher for $\mathrm{Co}-\mathrm{Pd} / \mathrm{SBA}-15$. Large pore properties of $\mathrm{Co}-\mathrm{Pd} / \mathrm{MA}$ provide longer residence time for reactant and lead to formation of long-chain hydrocarbons inside the mesopores [46]. In addition, larger pore size of the catalyst facilitates higher hydrocarbon selectivity [37]. Product distribution of FT synthesis is presented by classical Anderson Schulz-Flory (ASF) equation, which is a kinetic model to describe the product distribution. Slope obtained from this plot $\log (\mathrm{Wn} / n)$ versus carbon number (where " $n$ " is carbon number, "Wn" is the mole percentage of the component) referred as chain growth probability $(\alpha)$, which is given by equation (2) [47]. Figure 11 shows non-linear nature of the plot signifying non-ASF FTS product distribution. However, a line of best fit to the data for carbon numbers $\mathrm{C}_{10}-\mathrm{C}_{20}$ is used to obtain chain growth probability $(\alpha)$ for the catalysts (Tab. 5). The value of $\alpha$ is 0.80 for $\mathrm{Co}-$ $\mathrm{Pd} / \mathrm{MA}$, indicating formation higher molecular mass products like gasoline, kerosene and diesel [48],

$$
\log \frac{W_{n}}{n}=n \log \alpha+\log \frac{(1-\alpha)^{2}}{\alpha} .
$$

Table 5. Hydrocarbon Products in FT Synthesis with $\mathrm{Co}-\mathrm{Pd} / \mathrm{MA}$, and Co-Pd/SBA-15.

\begin{tabular}{lcccccccc}
\hline Catalyst & \multicolumn{3}{c}{ Conversion $\%$} & & \multicolumn{3}{c}{ Selectivity $\%$} & \\
\cline { 2 - 4 } \cline { 6 - 8 } & $\mathrm{CO}$ & $\mathrm{H}_{2}$ & $\mathrm{CH}_{4}$ & & $\mathrm{C}_{2}-\mathrm{C}_{5}$ & $\mathrm{C}_{6}-\mathrm{C}_{12}$ & $\mathrm{C}_{13}-\mathrm{C}_{20}$ & \\
\hline $\mathrm{Co}-\mathrm{Pd} / \mathrm{MA}$ & 64.76 & 58.52 & 10 & 5 & 38.3 & 46.7 & 0.80 \\
$\mathrm{Co}-\mathrm{Pd} / \mathrm{SBA}-15$ & 59.27 & 58.6 & 15.2 & 12 & 57.5 & 15.12 & 0.75 \\
\hline
\end{tabular}




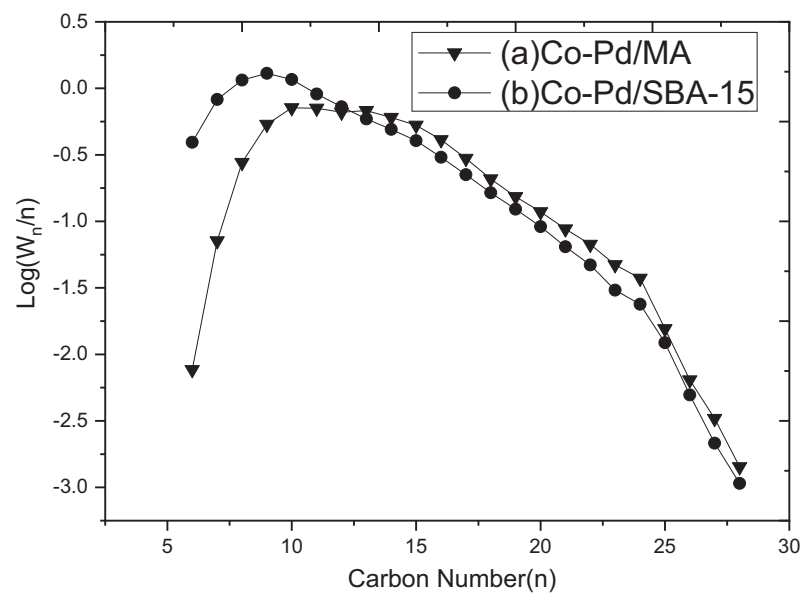

Fig. 11. ASF distributions of FT products for (a) $\mathrm{Co}-\mathrm{Pd} / \mathrm{MA}$, and (b) $\mathrm{Co}-\mathrm{Pd} / \mathrm{SBA}-15$ catalysts.

\section{Conclusion}

The Fischer-Tropsch synthesis experiments have been carried out over $\mathrm{Co}-\mathrm{Pd} / \mathrm{MA}$ and $\mathrm{Co}-\mathrm{Pd} / \mathrm{SBA}-15$ catalysts. The addition of 0.1 wt.\% quantity of palladium not only improved the reduction in cobalt oxides, but also promoted the reduction in cobalt silicate/cobalt aluminate interactions. $\mathrm{CO}$ conversion is achieved $64.76 \%$ for $\mathrm{Co}-\mathrm{Pd} / \mathrm{MA}$ while $59.27 \%$ for $\mathrm{Co}-\mathrm{Pd} / \mathrm{SBA}-15 . \mathrm{Pd} / \mathrm{SBA}-15$ has resulted higher selectivity of lower hydrocarbon, in contrast $\mathrm{Co}-\mathrm{Pd} /$ SBA-15 catalyst shows higher selectivity towards middle distillate. Hence, the selection of an appropriate support with optimum surface area, pore size, acidity, and basicity is essential for syngas conversion studies. The present study thus provides a better understanding of FT synthesis over mesoporous supports for formation of liquid hydrocarbon from syngas.

Acknowledgments. The authors are thankful Director, CSIR$C I M F R$, Dhanbad for permission to publish this paper and also acknowledged the Director, CSIR-CSMCRI, Bhawnagar for providing the TEM analysis.

\section{References}

1 Lešnik L., Kegl B., Torres-Jiménez E., Cruz-Peragón F. (2020) Why we should invest further in the development of internal combustion engines for road applications, Oil Gas Sci. Technol. - Rev. IFP Energies nouvelles 75, 56.

2 Maity S., James O.O., Chowdhury B., Auroux A. (2014) Effect of copper on calcium-modified alumina-supported cobalt catalysts towards Fischer-Tropsch synthesis, Curr. Sci. 106, 1538-1547.

3 Abbasi S., Abbasi M., Tabkhi F., Akhlaghi B. (2020) Syngas production plus reducing carbon dioxide emission using dry reforming of methane: utilizing low-cost Ni-based catalysts, Oil Gas Sci. Technol. - Rev. IFP Energies nouvelles 75, 22.

4 Yu L., Liu X., Fang Y., Wang C., Sun Y. (2013) Highly active $\mathrm{Co} / \mathrm{SiC}$ catalysts with controllable dispersion and reducibility for Fischer-Tropsch synthesis, Fuel 112, 483-488.
5 Yao M., Yao N., Shao Y., Han Q., Ma C., Yuan C., Li C., Li X. (2014) New insight into the activity of ZSM-5 supported Co and Co-Ru bifunctional Fischer-Tropsch synthesis catalyst, Chem. Eng. J. 239, 408-415.

6 Tursunov O., Kustov L., Kustov A. (2017) A brief review of carbon dioxide hydrogenation to methanol over copper and iron based catalysts, Oil Gas Sci. Technol. - Rev. IFP Energies nouvelles $\mathbf{7 2}, 30$.

7 Jacobs G., Das T.K., Zhang Y., Li J., Racoillet G., Davis B.H. (2002) Fischer-Tropsch synthesis: support, loading, and promoter effects on the reducibility of cobalt catalysts, Appl. Catal. A: Gen. 233, 263-281.

8 Jacobs G., Ji Y., Davis B.H., Cronauer D., Kropf A.J., Marshall C.L. (2007) Fischer-Tropsch synthesis: Temperature programmed EXAFS/XANES investigation of the influence of support type, cobalt loading, and noble metal promoter addition to the reduction behavior of cobalt oxide, Appl. Catal. A: Gen. 333, 177-191.

9 Bessell B. (1993) Support effects in cobalt-based FischerTropsch catalysis, Appl. Catal. A: Gen. 96, 253-268.

10 Spadaro L., Arena F., Granados M.L., Ojeda M., Fierro J.L.G., Frusteri F. (2005) Metal support interactions and reactivity of $\mathrm{Co} / \mathrm{CeO}_{2}$ catalysts in the Fischer-Tropsch synthesis reaction, J. Catal. 34, 451-462.

11 Wang H., Willot F., Moreaud M., Rivallan M., Sorbier L., Jeulin D. (2017) Numerical simulation of hindered diffusion in $\gamma$-alumina catalyst supports, Oil Gas Sci. Technol. - Rev. IFP Energies nouvelles 72, 8.

12 Storsæter S., Tøtdal B., Walmsley J.C., Tanemn B.S., Holmen A. (2005) Characterization of alumina, silica, and titania-supported cobalt Fischer-Tropsch catalysts, J. Catal. 236, 139-152.

13 Schanke D., Vada S., Blekkan E.A., Hilmen A.M., Hoff A., Holmen A. (1995) Study of Pt-Promoted Cobalt CO Hydrogenation Catalysts, J. Catal. 156, 85-95.

14 Vada S., Hoff A., Adnanes E., Schanke D., Holmen A. (1995) Fischer-Tropsch synthesis on supported cobalt catalysts promoted by platinum and rhenium, Top. Catal. 2, 155-162.

15 Xu D., Li W., Duan H., Ge Q., Xu H. (2005) Reaction performance and characterization of $\mathrm{Co} / \mathrm{Al}_{2} \mathrm{O}_{3}$ FischerTropsch catalysts promoted with $\mathrm{Pt}, \mathrm{Pd}$ and $\mathrm{Ru}$, Catal. Lett. 102, 229-235.

16 Lapidus A.L., Tsapkina M.V., Krylova A.Y. (2005) Bimetallic cobalt catalysts for the synthesis of hydrocarbons from $\mathrm{CO}$ and $\mathrm{H}_{2}$, Russ. Chem. Rev. 74, 577-586.

17 Guczi L., Borkó L., Schay Z., Bazin D., Mizukami F. (2001) $\mathrm{CO}$ hydrogenation and methane activation over $\mathrm{Pd}-\mathrm{Co} / \mathrm{SiO}_{2}$ catalysts prepared by sol/gel method, Catal. Today 65, 51-57.

18 Liu Z., Li X., Asami K., Fujimoto K. (2005) Insights into a multifunctional hybrid catalyst composed of $\mathrm{Co} / \mathrm{SiO}_{2}$ and $\mathrm{Pd} /$ Beta for isoparaffin production from syngas, Ind. Eng. Chem. Res. 44, 7329-7336.

19 Jin Y., Yang R., Mori Y., Sun J., Taguchi A., Yoneyama Y., Abe T., Tsubaki N. (2013) Preparation and performance of Co based capsule catalyst with the zeolite shell sputtered by $\mathrm{Pd}$ for direct isoparaffin synthesis from syngas, Appl. Catal. A. 456, 75-81.

20 Ribeiro M.C. (2009) Electroless cobalt alloys: magnetic and catalytic properties, PhD Thesis, Instituto de Quimica, Universidade de Sao Paulo.

21 Belousov V.M., Stoch J., Batcherikova I.V., Rozhkova E.V., Lyashenko L.V. (1989) Low-temperature hydrogen reduction 
of pure $\mathrm{Co}_{3} \mathrm{O}_{4}$ and doped with palladium, Appl. Surf. Sci. 35, 481-494.

22 Sarkany A., Zsoldos Z., Stefler G., Hightower J.W., Guczi L. (1995) Promoter Effect of Pd in Hydrogenation of 1, 3-Butadiene over Co-Pd Catalysts, J. Catal. 157, 179-189.

23 Guczi L., Schay Z., Stefler G., Mizukami F. (1999) Bimetallic catalysis: CO hydrogenation over palladium-cobalt catalysts prepared by sol/gel method, J. Mol. Catal. A Chem. 141, 177-185.

24 Murdoch Trant A.G., Gustafsona J., Jones T.E., Noakes T.C.Q., Bailey P., Baddeley C.J. (2016) The influence of CO adsorption on the surface composition of cobalt/palladium alloys, Surf. Sci. 646, 31-36.

25 Panpranot J., Tangjitwattakorn O., Praserthdam P., Goodwin J.G. Jr. (2005) Effects of Pd precursors on the catalytic activity and deactivation of silica-supported $\mathrm{Pd}$ catalysts in liquid phase hydrogenation, Appl. Catal. A Gen. 292, $322-327$.

26 Karnjanakom S., Bayu A., Hao X., Kongparakul S., Samart C., Abudula A., Guan G. (2016) Selectively catalytic upgrading of bio-oil to aromatic hydrocarbons over Zn, Ce or Ni-doped mesoporous rod-like alumina catalysts, J. Mol. Catal. A: Chem. 421, 235-244.

27 Ding Y., Yin G., Xi Liao, Huang Z., Chen X., Yao Y., Li J. (2013) A convenient route to synthesize SBA-15 rods with tunable pore length for lysozyme adsorption, Microporous Mesoporous Mater. 170, 45-51.

28 Lu Y., Zhou P., Han J., Yu F. (2015) Fischer-Tropsch synthesis of liquid hydrocarbons over mesoporous SBA-15 supported cobalt catalyst, RSC Adv. 5, 59792-59803.

29 Vosoughi V., Badoga S., Dalai A.K., Abatzoglou N. (2017) Modification of mesoporous alumina as a support for cobaltbased catalyst in Fischer-Tropsch synthesis, Fuel Process. Technol. 162, 55-65.

30 Cejka J., Balcar H. (2003) Mesoporous molecular sieves as supports for metathesis catalysts, in: Metathesis Chemistry From Nanostructure Design to Synthesis of Advanced Materials, pp. 151-166.

31 Zhao D., Huo Q., Feng J., Chmelka B.F., Stucky G.D. (1998) Nonionic triblock and star diblock copolymer and oligomeric surfactant syntheses of highly ordered, hydrothermally stable, mesoporous silica structure, J. Am. Chem. Soc. 120, 6024-6036.

32 Margolese J.D., Melero S.A., Christiansen C., Chmelka B.F., Stucky G.D. (2000) Direct syntheses of ordered SBA-15 mesoporous silica containing sulfonic acid groups, Chem. Mater. 12, 2448-2459.

33 Osakoo N., Henkel R., Loiha S., Roessner F., Wittayakun J. (2014) Effect of support morphology and Pd promoter on Co/SBA-15 for Fischer-Tropsch Synthesis, Catal. Commun. 56, 168-173.
34 Montes de Correa C., Córdoba Castrillón F. (2005) Supported bimetallic $\mathrm{Pd}-\mathrm{Co}$ catalysts: characterization and catalytic activity, J. Mol. Catal. A: Chem. 228, 267-273.

35 Hossain M.M. (2011) Co-Pd/ $\gamma$-Al2O3 Catalyst for heavy oil upgrading: desorption kinetics, reducibility and catalytic activity, Can. J. Chem. Eng. 9999, 1-10.

36 Khodakov A.Y., Chu W., Fongarland P. (2007) Advances in the development of novel cobalt Fischer-Tropsch catalysts for synthesis of long-chain hydrocarbons and clean fuels, Chem. Rev. 107, 1692-1744.

37 Tsubaki N., Sun S., Fujimoto K. (2001) Different functions of the noble metals added to cobalt catalysts for FischerTropsch synthesis, J. Catal. 199, 236-246.

38 Yuanyuan S., Kongyong L., Jinlin L.I. (2009) Effect of silylation of SBA-15 on its supported cobalt catalysts for Fischer-Tropsch synthesis, Chin. J. Catal. 30, 1091-1095.

39 Arnoldy P., Moulijn J.A. (1985) Temperature-programmed reduction of $\mathrm{CoOAI}_{2} \mathrm{O}_{3}$ catalysts, J. Catal. 93, 38-54.

40 Martínez A., López C., Màrquez F., Díaz I. (2003) FischerTropsch synthesis of hydrocarbons over mesoporous $\mathrm{Co} /$ SBA-15 catalysts: the influence of metal loading, cobalt precursor, and promoters, J. Catal. 220, 486-499.

41 Xiong H., Zhang Y., Liew K., Li J. (2009) Ruthenium promotion of $\mathrm{Co} / \mathrm{SBA}-15$ catalysts with high cobalt loading for Fischer-Tropsch synthesis, Fuel Sci. Technol. 90, 237-246.

42 Kumar N., Smith M.L., Spivey J.J. (2012) Characterization and testing of silica-supported cobalt-palladium catalysts for conversion of syngas to oxygenates, J. Catal. 289, 218-226.

43 Jean-Marie A., Griboval-Constant A., Khodakov A.Y., Diehl F. (2009) Cobalt supported on alumina and silicadoped alumina: Catalyst structure and catalytic performance in Fischer-Tropsch synthesis, CR Chim. 12, 660-667.

44 Mu S., Li D., Hou B., Jia L., Chen J., Sun Y. (2010) Influence of $\mathrm{ZrO}_{2}$ loading on SBA-15-supported cobalt catalysts for Fischer-Tropsch synthesis, Ener. Fuels 24, 3715-3718.

45 Mandal S., Maity S., Gupta P.K., Mahato A., Bhanja P., Sahu G. (2018) Synthesis of middle distillate through low temperature Fischer-Tropsch (LTFT) reaction over mesoporous SDA supported cobalt catalysts using syngas equivalent to coal gasification, Appl. Catal. A Gen. 557, 55-63.

46 Ohtsuka Y., Arai T., Takasakz S., Tsubouchi N. (2003) Fischer-Tropsch synthesis with cobalt catalysts supported on mesoporous silica for efficient production of diesel fuel fraction, Ener. Fuels 17, 804-809.

47 Shi B., Davis B.H. (2004) Fischer-Tropsch synthesis: accounting for chain-length related phenomena, Appl. Catal. A Gen. 277, 61-69.

48 Albuquerque J.S., Costa F.O., Barbosa B.V.S. (2019) FischerTropsch synthesis: analysis of products by Anderson-SchulzFlory distribution using promoted cobalt catalyst, Catal. Lett. 149, 831-839. 